\title{
KONTRIBUSI IMAM AL-RÂFI'Î DAN IMAM AL-NAWAWÎ DALAM PENATAAN KERAGAMAN PENDAPAT HUKUM MAZHAB SHÂFI'Î
}

\author{
Abdul Mun'im Saleh \\ Sekolah Tinggi Agama Islam Negeri Ponorogo, Indonesia \\ E-mail: abd_munim@yahoo.com
}

\begin{abstract}
The diversity of legal opinions in the Shâfi'î school of thought (madhhab), in the form of old opinion (qawl qadim) and new opinion (qawl jadîd) and the ijtihâd activities that pertained to some centuries after the passing away of alShâfi î̀, has brought this madhbab into encounter with serious problems in selecting the law. In such a situation, al-Râfîî and al-Nawawî came into the fore as mubarrir (selector) to cope with this uncertainty. This research tries to analyze all scientific activities of the two scholars using the theory of tarjîn. This research found out that they attempted to establish a legal certainty in the Shâficî school of law through the making of new mixed system of tarith to ensure which opinions deserve to be regarded as valid from the viewpoint of Shâfî̀ madhhab. This achievement contributes to the enrichment of Shâfiìmadhhab as a legal school consisting of a great variety of legal opinions that equips itself with procedures of selection used as norms of everyday life.
\end{abstract}

Keywords: Old opinion, new opinion, madhbab, muharrir, tarjıิth.

\section{Pendahuluan}

Adanya qawl qadîm dan qawl jadìd dalam mazhab Shâfîi merupakan khazanah melimpah dalam pendapat hukum Islam. Akan tetapi di sisi lain hal itu justru dapat menyulitkan dalam tataran implementasi sebuah fatwa yang menghendaki kepastian hukum. Ditambah lagi kegiatan ijtihâd yang dilakukan oleh așhâb al-Shâfîi seperti Imam alMuzanî, Imam al-Ḥaramayn, Imam al-Ghazâlî, dan beberapa tokoh lain yang melahirkan beragam pendapat tentang masalah yang sama. Oleh karena itu, diperlukan upaya tarîh (seleksi pendapat) untuk memilih pendapat yang terkuat. Dalam kaitan ini tercatat kontribusi luar biasa Imam al-Râfîî dan Imam al-Nawawî sebagai penyeleksi 
(murajjîh) yang hasil-hasilnya dituangkan dalam kitab-kitab yang ditulisnya. Tak pelak, karya keduanya menempati urutan kedua setelah karya-karya Imam al-Shâfîî. Artinya, untuk mengetahui bagaimana pendapat mazhab Shâfîî tentang sebuah masalah, maka pintu awal yang harus ditelusuri adalah karya mereka berdua. Otoritas al-Râfîi dan al-Nawawî ini menyebabkan hampir semua kitab yang mereka tulis mendapatkan apresiasi para ulama sesudahnya. Pada mulanya alRâfîî menulis kitab al-Muharrar, yang kemudian diringkas oleh alNawawî dalam kitab Minhâj al-Ṭâlibîn. Kitab tersebut dikembangkan oleh Ibn Hajar al-Haytamî (w. 974 H.) dan Shams al-Dîn Muhammad al-Ramlî (w. 1004 H.), al-Khațîb al-Sharbînî (w. 977 H.) dan Zakarîyâ al-Anșârî̀ (w. 926 H.) yang mengomentari kitab Minhâj al-Tâlibîn karya Imam al-Nawawî. Ibn Hajar al-Haytamî menuangkannya dalam Tuhfat al-Muḅtâj bi Sharḥ al-Minhâj', al-Sharbînî dalam Mughnî al-Mubtâj, alRamlî dalam Nihâyat al-Mụ̣tâj ilâ Sharḥ al-Minhâj, dan al-Anșârî Manhaj al-Tullâb.

Komentar atau ringkasan yang dilakukan keempat tokoh tersebut merupakan pengapresiasian terhadap ijtihâd al-Râfíî dan al-Nawawî dalam menyeleksi pendapat terkuat dalam mazhab Shâfîî. Berkaitan dengan hal ini, Ibn Hajar al-Haytamî (w. 974 H.) mengatakan dalam mukadimah kitabnya Tubfat al-Muḥtâj bi Sharḥ al-Minhâj:

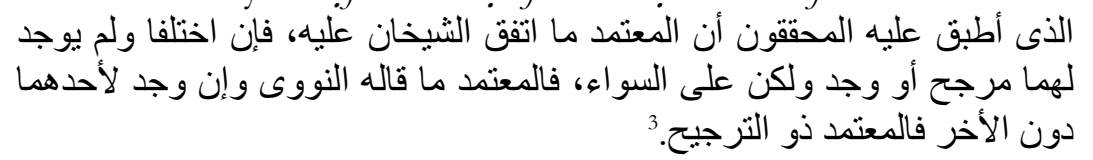

Para ulama menyepakati bahwa pendapat yang bisa dijadikan pegangan (dalam mazhab Shâfiî̀), ialah pendapat yang disepakati al-shay)khân (alNawawî dan al-Râfîî). Namun, apabila keduanya berbeda pendapat, dan tidak diketahui pendapat yang râjị dari keduanya, atau dapat diketahui, tetapi cukup berimbang, maka pendapat al-Nawawîlah yang lebih kuat.

\footnotetext{
1 Kitab ini dicetak beberapa kali dan mempunyai dua hâshiyah, yaitu Hâshiyat al'Allâmah Aḥmad b. Qâsim al-Ubadî̀ (w. 994 H.) dan Hầshiyat al-'Allâmah 'Abd alHamîd al-Sharwanî.

${ }^{2}$ Kitab ini juga dicetak beberapa kali dan mempunyai dua hâashiyah, yakni Hâshiyat al'Allâmah Nûr al-Dîn 'Alì b. 'Alî al-Shibrâmalisî̀ (w. 1087 H.) dan Hầshiyat al-'Allâmah Aḥmad 'Abd al-Razzâq yang dikenal dengan sebutan al-Maghribî al-Râshidî (w. 1096 H.).

${ }^{3}$ Muhammad 'Alî Jum'ah, al-Madkhal ilâ Dirâsat al-Madhâhib al-Fiqhîyah (Kairo: Dâr al-Salâm, t.th.), 49 .
} 
Tetapi, jika ditemukan pendapat yang râjị̆ dari keduanya, maka pendapat itulah yang dijadikan pegangan.

Dari paparan di atas, muncul pertanyaan apa kontribusi al-Râfi î̀ dan al-Nawawî sehingga pantas menyangga otoritas tinggi dalam mazhab Shâfîî. Untuk itu artikel ini ingin menguji kegiatan ilmiah yang telah mereka berdua lakukan untuk kemudian dianalisis dengan teori tarì̄ yang telah digagas oleh para ahli usûul al-fiqh (usûlîyun) sebagaimana didapatkan pada literatur usûul al-fiqh.

\section{Tarjị̂h dalam Hukum Islam}

Secara leksikal, perkataan tarị̄̌ adalah masdar dari kata Arab rajjahyurajjịh-tariłh hâ yang secara etimologi, sebagaimana dalam kitab alTa'rifât, karya 'Alî b. Muhammad al-Jurjânî, bermakna:

$$
\text { الترجيح هو اثبات مرتبة فى احد الدليلين على الاخر4 }
$$

Tarjî̀ adalah menetapkan atau menguatkan salah satu dari dua dalil.

Makna ini mengisyaratkan dengan jelas tentang kebutuhan mengutamakan salah satu dalil ketika terjadi pertentangan antar-dalil yang tidak dapat dikompromikan dengan jalan al-jam" wa al-tanfíq. Dalil yang dipastikan lebih kuat disebut dengan râjị atau unggul, sedangkan dalîl yang lain yang dianggap lebih lemah disebut marjụh (kalah unggul).

Adapun pengertian tarìth secara terminologi adalah:

a. Menurut ulama Hanafíyah:

$$
\text { الترجيح هو اظهار زيادة لأحد المتماتلين على الاخر بما لا يستقل5 }
$$

Tarjì adalah menjelaskan tambahan (kualitas) pada salah satu dari dua dalil yang setara, di mana dalil tambahan tersebut tidak independen.

Berdasarkan definisi di atas, dapat dipahami bahwa tarjît terjadi ketika terdapat dua dalil yang bertentangan dan mempunyai kekuatan yang sama (sederajat). Untuk memilih mana yang akan diunggulkan atau dimenangkan, diperlukan dalil lain sebagai pendukungnya.

b. Jumhûr ulama mendefinisikan tarjîh:
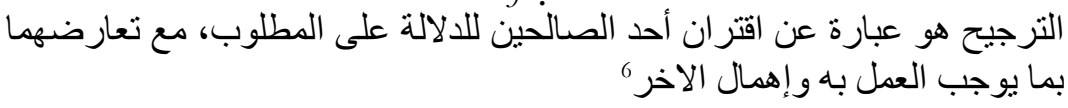

4 'Alî b. Muhammad b. 'Alî al-Jurjânî, al-Ta'riffât (Singapura: al-Ḥaramayn, t.th.), 56.

5 Sayf al-Dîn al-Âmidî, al-Iḥkâm fì Usûl al-Ạ̣kâm, Vol. 3 (Beirut: Dâr al-Kutub al'Ilmîyah, 1983), 174.

${ }^{6}$ Ibid., 460. 
Tarjī adalah ungkapan dari dua dalil yang sesuai untuk dijadikan dasar dalam memecahkan masalah dengan keharusan menggunakan salah satu dan membuang yang lain.

Dari beberapa kutipan definisi tersebut di atas, dapat dipahami bahwa yang dimaksud dengan tarî̀ ha adalah upaya untuk memperoleh atau memberikan penilaian lebih kuat terhadap alasan-alasan atau dalil-dalil yang dipilih atas dalil-dalil yang tidak terpilih. Hakikat dan tujuan dari definisi tersebut adalah sama, yaitu menguatkan salah satu dari dua dalil yang sama untuk diamalkan.

Para uşulîy ûn menglasifikasikan cara-cara tarjîh, secara garis besar, ke dalam dua model, yaitu: al-tarjîh bayn al-nusûs, yaitu menguatkan salah satu nașs (ayat atau hadîth) yang saling bertentangan, dan al-tarjîth bayn al-aqyisah, yaitu menguatkan salah satu qiyâs (analogi) yang saling bertentangan.

Yang dimaksud dengan al-tarjì̆ bayn al-nusûs adalah menguatkan salah satu nașs (ayat atau hadith) yang kontradiktif. Untuk mengetahui kuatnya salah satu nașs yang kontradiktif, ada beberapa cara yang bisa ditempuh, yaitu dengan cara men-tarjîh dari segi sanad (para perawi hadîth), matn (teks) ḥadîth, hukum atas kandungan hadîth (madlî̀), dan tarjîh dengan menggunakan faktor (dalil) lain di luar nașs (al-amr alkhârij). ${ }^{8}$

Adapun al-Tarjịh bayn al-nusûs dengan berbagai cara yang disebutkan di atas berlaku dalam konteks ta'ârud (pertentangan) antara dua dalil shara' yang berupa naș. Di samping itu ada ta'ârud yang terjadi antara dua dalil shara' yang bukan naș yaitu ta ârud antara qiyâs dengan qiyâs. Muhammad b. 'Alî al-Shawkânî mengemukakan tujuh belas macam tarì h̆ dalam persoalan qiyâs yang saling bertentangan. Ketujuh belas macam tarjì tersebut dikelompokkan oleh Wahbah alZuhaylî menjadi empat kelompok, yaitu: 1). Tarjî̀ dari segi hukum asal. 2). Tarjị̂ dari segi hukum furû́. 3) Tarjî̉ dari segi 'illat, dan 4) Tarjị̂ melalui faktor eksternal. ${ }^{10}$

\footnotetext{
${ }^{7}$ Wahbah al-Zuhaylî, Ușûl al-Fiqh al-Islâmî, Vol. 2 (Beirut: Dâr al-Fikr, 1998), 1216; Nasrun Haroen, Ushul Fiqh I (Jakarta: Logos Wacana, 2001), 197; dan Rachmat Syafe'i, Ilmu Ushul Fiqih (Bandung: Pustaka Setia, 1999), 243.

${ }^{8}$ Muḥammad b. 'Alî b. Muḥammad al-Shawkânî, Irshâd al-Fubûl (Beirut: Dâr al-Fikr, t.th.), 224; dan al-Zuhaylî, Ușûl al-Fiqh, Vol. 2, 1216.

${ }^{9}$ al-Shawkânî, Irshâd al-Fubûul, 224.

10 al-Zuhạlî, Usûul al-Fiqh, Vol. 2, 1228.
} 
Tarjịh model kedua di atas, oleh Yûsuf al-Qardâwî disebut dengan

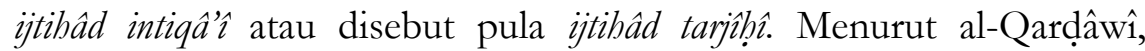
ijtihâd ini adalah ijtihâd yang dilakukan seseorang atau sekelompok orang untuk memilih pendapat para ahli fiqh terdahulu mengenai masalah-masalah tertentu, sebagaimana tertulis dalam berbagai kitab fiqh; kemudian menyeleksi mana yang lebih kuat argumentasinya secara situasional. ${ }^{11}$ Kemungkinan besar pendapat fuqaha yang tertuang di dalam kitab-kitab fiqh mengenai masalah yang sedang dipecahkan berbeda-beda. Dalam hal ini, seorang mujtabid bertugas untuk mempertimbangkan dan menyeleksi dalil-dalil dan argumentasiargumentasi itu, kemudian memberikan preferensinya terhadap suatu pendapat yang dianggap kuat dan dapat diterima. Contoh ijtihâd tarjî̀ adalah tentang harusnya meminta izin untuk menikahkan anak gadis.

Mazhab Shâfî̀i, Mâlikî, dan mayoritas golongan Hạbalî berpendapat sesungguhnya orang tua berhak memaksa anak gadisnya yang sudah dewasa untuk menikah dengan calon suami yang dipilih oleh orang tua. Argumentasi yang digunakan adalah karena orang tua lebih tahu tentang kemaslahatan anak gadisnya. Cara yang demikian itu mungkin masih dapat diaplikasikan pada seorang gadis yang belum mengenal sedikit pun kondisi dan latar belakang suaminya, sedangkan di era modern sekarang para gadis mempunyai kesempatan luas untuk belajar, bekerja, dan berinteraksi dengan lawan jenis dalam kehidupan ini. Akhirnya, hasil dari ijtihâd tarjîh ini adalah mengambil pendapat Abû Hanîfah yakni melibatkan urusan pernikahan kepada calon mempelai wanita untuk mendapatkan persetujuan dan izinnya. ${ }^{12}$

\section{Pemikiran Tarjîh Imam al-Râfi'î dan Imam al-Nawawî}

Dalam mazhab Shâfi'î, Imam al-Râfîî (w. 623 H.) dan Imam alNawawî (w. 676 H.) digolongkan sebagai mujtabid murajjị. Yang dimaksud al-mujtabid al-murajjĭ atau mujtabid al-tarjîth ${ }^{13}$ ialah mujtahid yang tidak hanya sekadar menghafalkan hasil ijtihâd imam mazhabnya melainkan mengetahui sumber-sumbernya, mampu menggambarkan dan menjelaskannya, meng-qiyâs-kan masalah dengan fiqh imam

11 Yûsuf al-Qarḍ̂wî, al-Ijtihâd fî al-Sharîah al-Islâmîyah (Kuwait: Dâr al-Qalam, 1985), 115. Lihat juga Fathurrahman Djamil, Metode Ijtihâd Majelis Tarjih Muhammadiyah (Jakarta: Logos Publishing House, 1987), 31-32.

12 Yusuf al-Qardawi, Ijtihad Kontemporer: Kode Etik dan Berbagai Penyimpangan, terj. Abu Barzani (Surabaya: Risalah Gusti, 1995), 34.

${ }^{13}$ Muḥammad Abû Zahrah, Usûl al-Fiqh (t.t.: Dâr al-Fikr, t.th.), 381; dan al-Zuhaylî, Ușul al-Fiqh, Vol. 1, 1080. 
mazhabnya bahkan menyeleksi pendapat yang kuat di antara pendapat-pendapat yang ada. ${ }^{14}$ Oleh karena itu, mujtabid tingkat ini disebut pula abl al-tarjị̂. ${ }^{15}$

\section{Sketsa Biografis Imam al-Râfi ${ }^{i} \hat{\imath}$}

Imam al-Râfi'î yang bernama lengkap Abû al-Qâsim 'Abd alKarîm b. Muḥammad b. al-Faḍl b. al-Ḥusayn b. al-Ḥasan al-Râfíî alQazwînî dilahirkan pada tahun $555 \mathrm{H}$. dan wafat pada tahun $623 \mathrm{H}$. Karir pendidikannya dimulai dari bapaknya sendiri yaitu Abû al-Fạ̣l Muhammad b. 'Abd al-Karîm b. al-Faḍl. ${ }^{16}$ Ia juga berguru ilmu fiqh kepada Muhammad b. Yahyyâ b. Manșûr. ${ }^{17}$ Karyanya yang berjudul alMuharrar demikian populer di kalangan mazhab Shâfîî, mengilhami kelahiran karya-karya lain segaya yang ditulis para ulama generasi setelahnya dari kalangan mazhab Shâfiî̀. Karyanya yang berjudul alSharḥ al-Saghîr merupakan sharḥ (komentar) dari kitab al-Ghazâlî yang berjudul al-Wajił: Sedangkan karya yang lain dengan judul Fath al-

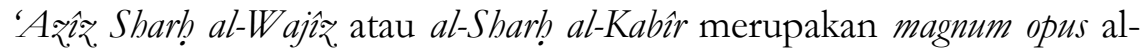
Râfi'î. Kitab ini merupakan sharḅ kedua dari kitab al-Wajî karya Abû Hâmid al-Ghazâlî, dengan sharḥ yang sangat luas dan panjang yang mengusulkan pemilihan pendapat-pendapat yang layak dipandang sebagai mazhab al-Shâfi î.

Beberapa ahli memberikan penghargaan kepada kontribusi alRâfi'î dalam pengembangan fiqh, khususnya dalam mazhab Shâfi $\hat{1}$, kepada upaya tarjị̂ atas pendapat-pendapat hukum. Di antara mereka adalah al-Subkî yang melukiskan al-Râfi'î sebagai rujukan para

\footnotetext{
14 Yahyâ b. Sharaf al-Nawawî, al-Majmû' Sharḥ al-Muhadhdhab, Vol. 1 (Beirut: Dâr alKutub al-'Ilmîyah), 1980, 73.

15 al-Zuhayli, Usûul al-Fiqh, Vol. 1, 396.

16 Ayah al-Râfi'î, alumnus Universitas Nizâmîyah-Baghdad, adalah imam besar yang sangat terpandang. Ia belajar hadîth dari Abû al-Barakah al-Farawî, 'Abd al-Khâliq al-Shahamî. Ia belajar fiqh kepada Malkadad al-Qazwînî dan Abû Manșûr al-Râzî di Baghdad. Kemudian, ia pindah ke Nisapur dan belajar fiqh kepada Muhammad b. Yahyâ. Lihat Abdussalam, Ensiklopedia Imam Syafi i, terj. Usman Sya'roni Jakarta: Hikmah, 2008), 608.

${ }^{17}$ Ia adalah imam besar yang menjadi guru dari ulama-ulama Nisapur. Ia merupakan murid dari al-Ghazâlî dan Abû Muẓaffar al-Khawâfî. Ia merupakan ulama yang menjadi rujukan dalam mengungkap perbedaan pendapat antara mazhab Shâfi î dan mazhab Hanafi. Lihat ibid.
} 
penyeleksi pendapat (muhaqqiq). ${ }^{18}$ Al-Isfarâyînî menilai al-Râfîî layak disebut sebagai mujtahid madhhhab pada zamannya. ${ }^{19}$ Al-Nawawî menobatkan al-Râfîî sebagai pemimpin para pen-tahqî́q. ${ }^{20}$ Sedangkan Muhammad al-Khatîib al-Sharbînî mengisahkan kehebatan al-Râfî̀̂, bahwa ketika ia menulis kitab tidak ada penerangan lampu, pohon dan rantingnya justru yang menyinari suasana saat itu. ${ }^{21}$

Metode tarjîh yang digunakan al-Râfîi digambarkan oleh Imam alNawawî di dalam kitab Rawdat al-Tâlibîn sebagai berikut:

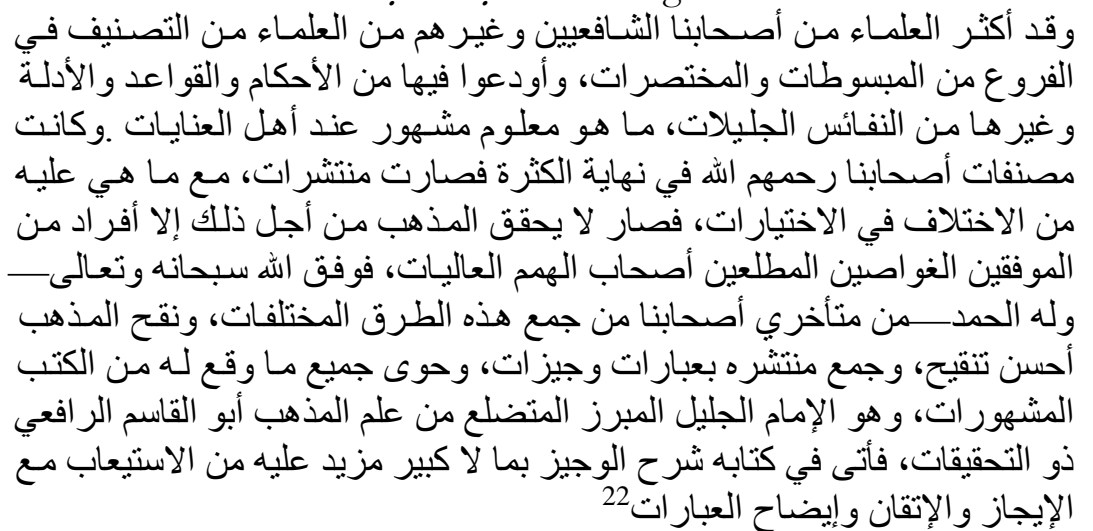

Para ulama dari kalangan mazhab al-Shâfîî maupun yang lain telah beramai-ramai menulis kitab-kitab fiqh (furu') baik yang dengan uraian panjang-lebar (mabsûtât) maupun yang berbentuk ringkasan. Lewat karya-karya tersebut, mereka membahas berbagai persoalan besar dan menarik bagi pemerhati (fiqh), meliputi berbagai persoalan hukum, kaidah, dan argumentasinya. Karya-karya ulama mazhab Shâfiî̀ tersebut sangat banyak dan memuat berbagai perselisihan pendapat ulama, sehingga hanya beberapa ulama saja yang mampu memilih pendapat yang kuat. Mereka adalah ulama yang mendapatkan pertolongan Allah, mempunyai perhatian yang kuat (dalam mengembangkan fiqh), dan bercita-cita luhur. Sampai akhirnya, Allah memberikan anugerah kepada tokoh muta'akbkhirin dari ulama Shâfi îyah, yang mampu mengoleksi dan

\footnotetext{
18 Tâj al-Dîn Abû Naṣr 'Abd al-Wahhâb al-Subkî, Ṭabaqât al-Shâfi'ŷahah al-Kubrâ, Vol. 5 (Mesir: Fayșal 'Îsâ al-Bâbî al-Ḥalabî, 1964), 119; dan Ibn Khallikân, Wâfayât alA'yân, Vol. 2 (Beirut: Dâr al-Fikr, 1985), 7.

${ }^{19}$ Ibid.

${ }^{20}$ Ibid.

21 Muḥammad al-Sharbînî al-Khațîb, Mughnî al-Muḅtâj ilâ Ma'rifat Alfâz al-Minhâj, Vol. 1 (Beirut: Dâr al-Fikr, t.th.), 36.

22 Imâm al-Nawawî, Rawdat al-Ṭalibîn, Vol. 1 (Beirut: Dâr 'Âlim al-Kutub, t.th.), 112 113.
} 
menyeleksi pendapat-pendapat yang ada, mendeskripsikan dengan bahasa yang ringkas dan jelas, dan merangkum pemikiran-pemikiran dari kitab-kitab yang masyhur. Dia adalah Abû al-Qâsim al-Râfîî, sang pentaḥî́q (penyeleksi, penelaah), dengan kitabnya Sharḥ al-Wajî̌, kitab yang hampir-hampir mencakup semua masalah namun dengan penyajian yang ringkas, rapi, dan dengan bahasa yang jelas.

Dari pernyataan al-Nawawî di atas, setidaknya ada dua hal yang bisa diungkap terkait dengan tarǰ̣̂. yang dilakukan al-Râfi î. Pertama, dalam internal mazhab Shâfiî̀ terjadi dinamika kegiatan ijtihâd yang dilakukan oleh așhâb al-Shâfi î. Hasil ijtihâd mereka dituangkan dalam beberapa kitab, baik dalam bentuk mabsûtât maupun mukbtasar. Hanya saja, kebanyakan kitab-kitab tersebut hanya memaparkan secara deskriptif mengenai perbedaan pendapat di antara așhâb al-Shâfi î, tanpa disertai ulasan yang memadai mengenai pendapat mana yang lebih kuat. Hal tersebut, pada gilirannya menimbulkan kesulitan untuk memilih pendapat mana yang benar-benar merupakan mazhab Shâfi î̀ atau yang paling mendekatinya. Dalam kondisi yang demikian, sosok al-Râfîî tampil untuk menyeleksi (tarjîh) pendapat yang kuat sebagai pendapat resmi mazhab Shâfíî.

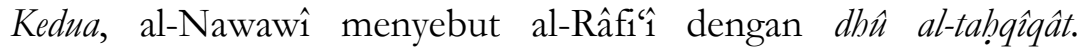
Artinya, dalam pemilihan pendapat yang terkuat, al-Râfíî menguji validitas dalil-dalil yang ada. Pendapat yang didasarkan pada dalil yang kuat, itulah yang dianggap sebagai pendapat mazhab Shâfi î. Contoh, jika ada musafir melaksanakan salat dengan tayamum, kemudian musafir tersebut ingat bahwa sebenarnya ia membawa air yang cukup untuk berwudu. Dalam kasus seperti ini, apakah musafir tersebut wajib mengulangi salatnya? Dalam kasus tersebut, ulama berbeda pendapat. Menurut Ibn Mundhir (w. 310 H.), al-Qâdî Abû Tayyib alṬabarî (w. 450 H.), al-Mâwardî (w. 450 H.), musafir tersebut tidak wajib mengulangi salatnya. Sedangkan pendapat lain menyebutkan bahwa ia harus mengulanginya. Pendapat yang kedua inilah yang dipilih oleh al-Râfî̀ sebagai pendapat yang terkuat. Menurutnya, musafir dianggap lalai sehingga harus mengulangi salatnya. Al-Râfi î menganalogkan kasus tersebut dengan orang yang lupa menutup aurat ketika salat dan orang yang lupa membasuh salah satu anggota wudu, di mana keduanya wajib mengulangi salat dan wudunya. ${ }^{23}$

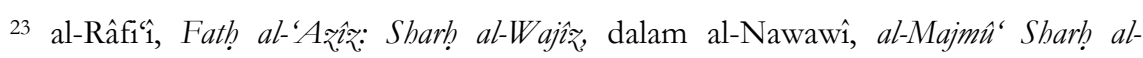
Muhadhdhab, Vol. 2, 257. 
Prinsip tarjîh al-Râfîî yang lain dapat dilihat dari penjelasan alNawawî di dalam kitab Minhâj al-Tâlibîn wa 'Umdat al-Muftîn. AlNawawî berkata:

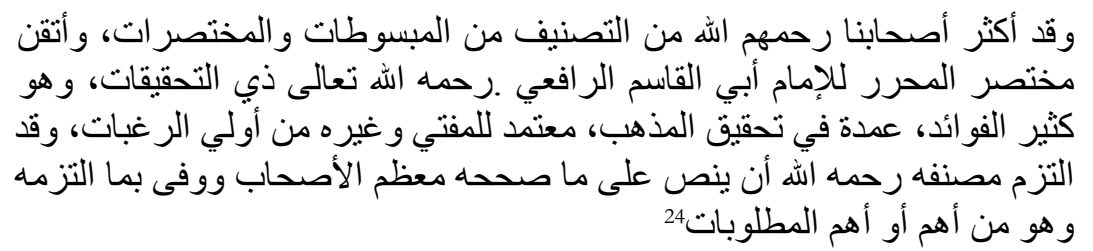

Para ulama dari kalangan mazhab al-Shâfîî telah banyak menghasilkan kitab-kitab fiqh baik dengan uraian panjang-lebar maupun uraian yang ringkas serta mengukuhkan ringkasan kitab al-Muharrar karya Imam alRâfiî̀ sebagai pedoman dalam melakukan penelitian mazhab al-Shâfi î, sekaligus sebagai pegangan bagi mufti dan peminat lainnya. Pengarang kitab al-Muharrar secara konsisten telah memastikan pendapat-pendapat yang disahkan oleh mayoritas ulama Shâfi îyah, dan hal itu merupakan buah karya yang sangat penting.

Pernyataan al-Nawawî an yunaṣs 'alâ mâ saḥhaḥah mu'zam al-aṣ̣âb di atas menunjukkan bahwa jika terjadi perbedaan pendapat antara Imam al-Shâfi'î dan pengikutnya, maka pendapat Imam al-Shâfi'î disebut qawl nass yang kedudukannya lebih tinggi dibanding pendapat așhâb. Contoh, ulama sepakat bahwa lelaki haram memakai pakaian yang terbuat dari sutera. Tetapi mereka berbeda pendapat, mengenai kebolehan orang tua yang mengenakan pakaian sutera kepada anaknya. Al-Baghawî berpendapat bahwa orang tua boleh melakukan hal tersebut dengan syarat si anak belum berumur tujuh tahun. Tetapi jika lebih tujuh tahun, maka hukumnya haram. Pendapat kedua mengharamkan secara mutlak, baik sebelum maupun setelah berumur tujuh tahun. Pendapat ketiga, yang dipilih oleh al-Râfi $\hat{1}$, orang tua boleh mengenakan pakaian sutera kepada anak secara mutlak. Pendapat ini sesuai dengan pendapat Imam al-Shâfi $1 \hat{i}^{25}$

\section{Sketsa Biografis Imam al-Nawawî}

Imam al-Nawawi, yakni Muhy al-Dîn Abû Zakarîyâ Yahyâ b. Sharaf al-Nawawî, ${ }^{26}$ lahir pada bulan Muharram tahun $631 \mathrm{H}$. di

${ }^{24}$ Imâm al-Nawawî, Minhâj al-Tâlibîn wa Umdat al-Muftin, Vol. 1 (Jeddah: Dâr alMinhâj, 2005), 64.

25 al-Nawawî, Rawdat al-Tâlibîn, Vol. 1, 170.

26 Ahmad Nahrowi Abdus Salam, Ensiklopedia Imam Syafi i, terj. Usman Sya'roni (Jakarta: Hikmah, 2008), 616. Bandingkan dengan Abû al-Fatḥ Mûsâ b. Muhammad 
Nawâ, sebuah kampung di daerah Damaskus, Suriah. Ia belajar fiqh kepada al-Kamâl al-Arbalî (w. 665 H.), ${ }^{27}$ Abû al-Ma'âlî al-Maghribî (w. 668 H.), ${ }^{28}$ Ibrahîm al-Murâdî (w. 668 H.) ${ }^{29}$ dan Kamâl al-Dîn al-Arbalî (w. 670 H.). ${ }^{30}$ Sedangkan dalam bidang hadìth, ia berguru kepada Tâj al-Dîn al-Fazarî (w. 670 H.). ${ }^{31}$

Al-Nawawî adalah salah satu ulama yang prolifik. Kitab Minhâj alTâlibîn, ringkasan dari kitab al-Muharrar karya Imam al-Râfîî, merupakani referensi terpenting di antara kitab-kitab periode pertama mazhab Shâfî̀. Kitab ini menjadi rujukan utama para ulama Shâfi'îyah dan banyak ulama tertarik memberikan sharḅ (komentar) dan hâshîyah (catatan) atas kitab ini. Di antara sharḅ kitab ini adalah Mughnî al-Muḅtâj karya al-Khatîb al-Sharbinî, al-Manbaj wa Sharḅuh karya Zakarîyâ al-Anșarî, Tuhfat al-Mubtâj karya Ibn Ḥajar al-Haytamî, dan Nihâyat al-Muḥtâj karya Imam al-Ramlî. Selanjutnya, al-Majmû́ Sharḅ al-Muhadhdhab merupakan master piece al-Nawawî yang mengomentari al-Muhadhdhab karya Abû Ishậq al-Shayrâzî (w. 476 H.). ${ }^{32}$ Kemudian al-Minbâj Sharḅ Șahîh Muslim b. al-Hajjâj adalah kitab sharh terpenting dan terbaik di antara sharḅ Șahị̂ Muslim lainnya.

al-Yûnanî, Dhayl Mir'ât al-Zamân,Vol. 3 (India: al-Maṭba'ah al-'Uthmânîyah, 1374 H), 283.

${ }^{27}$ Nama lengkap al-Kamâl al-Arbalî (w. 665 H.) adalah Abû 'Abd Allâh Aḥmad Yahyâ. Ia merupakan ahli fiqh dan seorang zâhid di masanya. Lihat Abdus Salam, Ensiklopedia, 611.

${ }^{28}$ Nama lengkap Abû al-Ma'âlî (w. 668 H.) adalah Ishâaq b. 'Abdillâh. Ia termasuk ahli fiqh dan ahli sastra. Lihat ibid.

${ }^{29}$ Nama lengkap Ibrahîm al-Murâdî adalah Ibrahîm b. 'Îsâ al-Murâdî al-Andalûsî. Menurut al-Nawawî, Ibrahîm adalah ahli fiqh, penghafal hadîth, orang yang terpercaya, zâhid, dan sangat wara: Ia orang yang menguasai hadîth dan ilmu-ilmu hadîth, mampu meneliti redaksi ḥadîth, mempunyai perhatian serius di bidang bahasa, nabw, fiqh, dan tasawwuf. Lihat ibid.

${ }^{30}$ Nama lengkap Kamâl al-Dîn al-Arbalî (w. 670 H.) adalah Abû al-Faḍl Salah b. Hasan b. 'Umar al-Arbalî. Al-Nawâwi berkata: "Ia adalah guru kami yang kepemimpinan dan kemuliaannya tidak diragukan lagi. Ia sangat menguasai mazhab Shâfi'î dari berbagai aspeknya". Lihat ibid.

${ }^{31}$ Nama lengkap Tâj al-Dîn al-Fazarî (w. 670 H.) adalah 'Abd al-Raḥmân b. Ibrahîm b. Diyâ' b. Sabbâ' al-Fazari al-Mișrî. Ia adalah ahli fiqh tanah Shâm. Ia belajar fiqh kepada 'Izz al-Dîn dan Taqî al-Dîn b. al-Ṣalâh. Di usia yang relatif muda, ia menguasai mazhab Shâfíî dengan baik. Lihat ibid.

32 al-Nawawî meninggal sebelum menyelesaikan kitab ini. Ia menulis kitab ini hanya sampai pada bab riba dari kitâb al-buŷú. Kemudian Imam Taqîyy al-Dîn al-Subkî (w.

756 H.) melanjutkan apa yang telah dimulai oleh al-Nawawî, namun al-Subkî 
Al-Nawawî, melalui karya-karyanya di atas, menyeleksi pendapatpendapat dalam mazhab Shâfîî. Alasannya, menurut al-Nawawî, ada beberapa kalangan yang menilai bahwa kitab-kitab para aṣhâb al-Shâfi sulit dijadikan pedoman dalam berfatwa. ${ }^{33}$ Maka dalam mukadimah

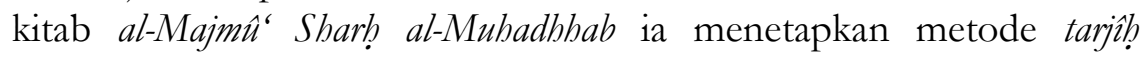
sebagai berikut:

1. Jika pendapat al-Shâfîî baik dalam qawl qadîm maupun qawl jadîd bertentangan dengan hadîth sahîh, maka qawl tersebut harus ditinggalkan, dan hadîth tersebut diambil sebagai pendapat mazhab al-Shâfîî. Hal ini didasarkan pada arahan al-Shâfîî yang terkenal bahwa jika pendapatnya bertentangan dengan Sunnah Rasul, maka yang harus diikuti adalah Sunnah Rasul. ${ }^{34}$

2. Jika qawl jadîd bertentangan dengan qawl qadîm, maka qawl jadìd-lah yang dipandang sebagai mazhab Shâfî̀, karena prinsipnya semua fatwa al-Shâfíî dalam qawl qadîm telah ditinggalkan (marjù' 'anb) dan diganti oleh qawl jadîd. ${ }^{35}$ Namun, apabila qawl qadìm tidak bertentangan dengan qawl jadîd, atau tidak diketemukan pendapat al-Shâfîî dalam qawl jadî̀, maka qawl qadîm itulah yang dipandang sebagai mazhab Shâfîi dan itulah yang harus dijadikan pijakan dalam berfatwa. ${ }^{36}$

Apa yang merupakan keberhasilan monumental al-Nawawî adalah rumusannya tentang prinsip tarjîh, baik dalam rangka memilih pendapat yang terkuat di antara beberapa pendapat (qawl) dari alShâfi î, antara qawl al-Shâfi'î dengan pendapat (wajh) aș̣âb al-Shâfî̀ maupun antara așhâb al-Shâfi î. ${ }^{37}$ Berikut ini, beberapa istilah yang digunakan al-Nawawî di dalam kitab al-Minhâj dalam menyeleksi pendapat yang terkuat dalam mazhab Shâfi î:

1. Al-Az̧har. Kadangkala dalam suatu masalah, Imam al-Shâfî̀ mempunyai beberapa qawl berbeda, dengan perbedaan argumentasi yang sangat tajam. Perbedaan atau pertentangan qawl tersebut bisa

meninggal dunia setelah melengkapi sekitar tiga volume saja. Kemudian, ulama Shâfi'îyah yang lain mencoba melengkapinya, di antaranya, adalah al-'Allâmah 'Isâ b. Yûsuf Mannûn (w. 1376 H.) dan Muhammad Najîb al-Muṭ̂îi (w. 1406 H.).

33 al-Nawawî, al-Majmû' Sharh al-Muhadhdhab,Vol. 1, 47.

34 Ibid., 63.

${ }^{35}$ Ibid., 66.

36 Ibid.

37 al-Nawawî memberikan istilah qawl untuk menunjuk pendapat al-Shâfíî dan istilah wajh untuk menunjuk pendapat aṣhâab al-Shâfi î. 
saja terjadi sesama qawl qadîm, qawl jadîd atau antara qawl qadîm dan qawl jadìd. Qawl aşhar adalah qawl Imam al-Shâfi'î yang paling kuat. ${ }^{38}$

2. Al-Mashbûr. Mashbûr adalah qawl Imam al-Shâfi'î yang paling unggul dari beberapa qawl-nya dengan kontestasi yang tidak begitu kuat. Qawl mashbûr adalah salah satu qawl yang memiliki dalil yang paling kuat. ${ }^{39}$ Contohnya, așhâb al-shâfi î meriwayatkan bahwa alShâfîî memiliki dua pendapat (qawl) dalam masalah kesunnahan adhân dan iqâmah bagi salat jamaah wanita. Satu qawl menyatakan bahwa salat wanita yang dikerjakan secara berjamaah disunnahkan adhân dan iqâmah. Sedang qawl yang lain, hanya disunnahkan adhân saja. Menurut al-Nawawî, qawl yang mashbûr adalah qawl yang kedua. $^{40}$

3. Al-jadîd. Qawl jadîd adalah qawl Imam al-Shâfîî ketika berada di Mesir. ${ }^{41}$

4. Al-Naș. Jika terjadi perbedaan pendapat antara Imam al-Shâfi'î dan pengikutnya (așhâb), maka pendapat Imam al-Shâfi'î disebut qawl nass yang kedudukannya lebih tinggi dibanding pendapat (wajh) așâab. ${ }^{42}$ Contoh, dalam hal boleh tidaknya orang buta menjadi imam atas orang yang bisa melihat, antara așhâb al-Shâfi î dan alShâfi î̀ terjadi perbedaan pendapat. Așhâab al-Shâfi î̀ berpendapat boleh, tetapi kurang afdal, sedang al-Shâfîî berpendapat boleh secara mutlak. Menurut al-Nawawî, pendapat al-Shâfíî, dalam perbedaan di atas, disebut pendapat yang lebih diunggulkan (alnașs) dibandingkan pendapat așhâb al-Shâfi $\iota^{43}$

5. Al-Madhhab. Jika terjadi perbedaan di antara așâab al-Shâfič dalam meriwayatkan qawl al-Shâficî atau pendapat asḥâb al-Shâfici dalam sebuah masalah, misalnya sebagian meriwayatkan bahwa al-Shâfi $\hat{1}$ memiliki dua qawl dalam suatu masalah, sedangkan yang lain meriwayatkan hanya satu qawl, maka pendapat yang terkuat disebut

38 al-Nawawî, Minhâj al-Tâlibîn, Vol. 1, 2. Lihat juga Jalâl al-Dîn al-Mahallî, Hâshiyatayn al-Qalyûbî wa 'Umayrah, Vol. 1 (Semarang: Toha Putra, t.th.), 14. Muhammad 'Alî Jum'ah, al-Madkhal ilâ Dirâsat al-Madhâhib al-Fiqhîyah (Kairo: Dâr alSalâm, t.th.), 60 .

${ }^{39}$ Ibid.

40 al-Nawawî, Minhâj al-Ṭalibîn, Vol. 1, 23.

${ }^{41}$ Ibid.

42 Ibid.

43 al-Nawawî, Minhâj al-Ṭalibîn, Vol. 1, 48; dan Ibn Hajar al-Haytamî, Tuhfat alMuḥtâj bi Sharḥ al-Minhâj, Vol. 8 (Beirut: Dâr al-Fikr, t.th.), 61. 
al-mazhab. ${ }^{44}$ Contohnya, para aṣhâb berbeda pendapat tentang ketercukupan mandi (al-ghusl) bagi orang yang mempunyai hadath besar dan kecil, artinya tidak diperlukan wudu. Pendapat pertama menyatakan bahwa mandi dapat menghilangkan hadath besar maupun kecil, meskipun tidak diniati wudu. Pendapat kedua menyatakan bahwa, mandi hanya menghilangkan ḩadath besar saja. Sedangkan yang lain berpendapat, jika ketika melaksanakan mandi sekaligus diniati berwudu, maka mandi yang dilakukan dapat menghilangkan hadath kecil maupun besar sekaligus. Menyikapi perbedaan tersebut, Imam al-Nawawî melakukan tarjî̉ bahwa pendapat pertamalah sebagai pendapat yang dipilih (al-madbhab). ${ }^{45}$

6. Al-Asạ̣h. Jika aṣhâb memiliki pendapat yang berbeda-beda, dengan persaingan yang ketat, maka pendapat yang paling kuat disebut asaḥh. ${ }^{46}$ Contohnya, para așâb berbeda pendapat tentang status air musta'mal yang dikumpulkan hingga menjadi banyak (mencapai qullatayn). Sebagian berpendapat, bahwa hukum air tersebut menjadi suci dan dapat digunakan bersuci (tâhir mutabbir), sedangkan yang lain berpendapat hanya suci saja, tidak dapat digunakan untuk bersuci (tâhir ghayr mutabhir). Menyikapi perbedaan tersebut, Imam al-Nawawî melakukan tarì̄ bah bahwa pendapat pertamalah yang lebih sabî. ${ }^{47}$

7. Al-Sahîh. Jika aṣhâb memiliki pendapat yang berbeda-beda, maka wajh sabîh adalah pendapat yang kuat, sedangkan yang lemah disebut fâsid (rusak). ${ }^{48}$ Contohnya, para aş̧âb berbeda pendapat tentang orang yang berwudu dengan niat wudu sekaligus untuk mendinginkan tubuh. Sebagian berpendapat, niat tersebut diperbolehkan, sedangkan yang lain berpendapat tidak boleh, karena termasuk niat yang mendua. Menyikapi perbedaan tersebut, Imam al-Nawawî melakukan tarjị bahwa pendapat pertamalah yang sahîh, sedang pendapat yang kedua dianggap fâsid. ${ }^{49}$

\footnotetext{
${ }^{44}$ Ibid.

${ }^{45}$ Shams al-Dîn al-Ramlî, Nihâyat al-Muḅtâj ilâ Sharḥ al-Minhâj, Vol. 2 (Beirut: Dâr alKutub al-'Ilmîah, t.th.), 251.

${ }^{46}$ Muhammad, al-Madkhal ilâ Dirâsat al-Madhâhib, 60.

47 al-Nawawî, Minhâj al-Tâlibîn, Vol. 1, 4.

48 Muhammad, al-Madkhal ilâ Dirâsat al-Madhâhib, 60.

${ }^{49}$ al-Nawawî, Minhâj al-Tâlibîn, Vol. 1, 8.
} 


\section{Tarjị̆ sesudah al-Shaykhân: Pengaruhnya terhadap Mujtahid fî al-Fatwâa}

Imam al-Râfîî dan Imam al-Nawawî (al-Shaykhân) berkedudukan sangat penting dalam mazhab Shâfíi. Kitab-kitab yang mereka tulis menempati urutan otoritas kedua setelah karya-karya Imam Shâfîî dan merupakan pintu pertama ketika seseorang hendak mengetahui bagaimana pendapat mazhab Shâfî̀ tentang sebuah masalah. Keduanya memiliki bekal keberhasilan mempertemukan mazhab Shâfi'î aliran Khurâsân dan Irak, ${ }^{51}$ yang transmisi keilmuan keduanya bertemu pada al-Imâm Abû 'Amr b. al-Ṣalâh (w. 643 H.). Sedangkan Ibn al-Ṣalâh berguru kepada ayahnya yang bernama Abû al-Qâsim alȘalâh (w. 618 H.), dan dari ayahnya itulah, Ibn al-Ṣalâh mempelajari dua corak mazhab Shâfi $\hat{i}^{52}$

Berdasarkan penuturan al-Nawawî, kedua aliran di atas mempunyai kelebihan dan kekurangan masing-masing. Aliran Irak ('Irâqîyun) secara umum lebih tepat, lebih akurat dan lebih bisa dipertanggung-jawabkan dalam menukil nașs-nașs al-Shâfîi serta kaidah-kaidah yang ditetapkannya dibanding dengan kelompok Khurâsân (al-Khurâsânîyun). Sedang aliran Khurâsân secara umum memiliki kelebihan di dalam pengembangan fiqh mazhab, baik dari sisi sistematika dan analisis pembahasannya. ${ }^{53}$

Prestasi ini ditambah dengan keberhasilan mereka meletakkan prinsip-prinsip tarjı̆h menyebabkan keduanya disebut tokoh pemurnian mazhab Shâfîî. Sepeninggal mereka, beberapa tokoh dalam mazhab Shâfiî̀ di antaranya Abû Yahyâ Zakarîyâ al-Anșârî (w. 926 H.), Ibn Hajar al-Haytamî (w. 974 H.), al-Khatîib al-Sharbînî (w. 977 H.) dan Shams al-Dîn Muhammad al-Ramlî (w. 1004 H.), meneruskan rintisan al-Râfíî dan al-Nawawî. Mereka berempat memberikan komentar atas kitab Minhâj al-Ṭalibîn karya Imam al-

50 Ijtihâd yang dilakukan mujtahid dalam klasifikasi ini, di samping memelihara, meriwayatkan dan memahami fiqh mazhabnya, juga melakukan ijtihâd tariț. Namun, intensitas kegiatan tarjîh yang dilakukan mujtabid pada level ini hanya men-tarjîh halhal yang belum disinggung oleh mujtahid fî al-tarjî̀. Oleh karena itu, beberapa kalangan, seperti Ibn al-Qayyim, menyebut kelompok mujtahid ini sebagai muqallid. Tokoh mazhab Shâfi'î yang termasuk kelompok ini, antara lain, adalah Abû Zakarîyâ al-Anșârî, Ibn Hajar al-Haytamî, al-Khatîib al-Sharbînî, dan Shams al-Dîn Muhammad al-Ramlî.

${ }^{51}$ Muhammad, al-Madkhal ilâ Dirâsat al-Madhâhib, 34.

52 Ibid., 34-35.

53 al-Nawawî, al-Mahjmî̀' Sharḥ al-Muhadhdhab, Vol. 1, 69. 
Nawawî. Ibn Hajar al-Haytamî menulis sharḥ kitab Minbâj al-Tâlibîn dengan judul Tubfat al-Muḥtâj bi Sharḥ al-Minhâj.j. Al-Sharbînî menulis kitab Mughnî al-Mubtâj. Sedangkan al-Ramlî menulis kitab Nibâyat alMụ̣tâj ilâ Sharḥ al-Minhâj. ${ }^{55}$ Sedangkan Zakarîyâ al-Anșârî meringkas kitab Minhâj al-Ṭalibîn dengan judul Manbaj al-Tullâb. Upaya yang dilakukan empat tokoh tersebut, melalui sharḅ (komentar) dan mukbtașar (resume) dari kitab Minhâj al-Tâlibîn, merupakan bentuk apresiasi kepada hasil ijtihâd al-Râfî̀ dan al-Nawawî. Berkaitan dengan hal ini, Ibn Hajar al-Haytamî (w. 974 H.) mengatakan dalam mukadimah kitabnya Tubfat al-Mụ̣tâj bi Sharḥ al-Minhâj:

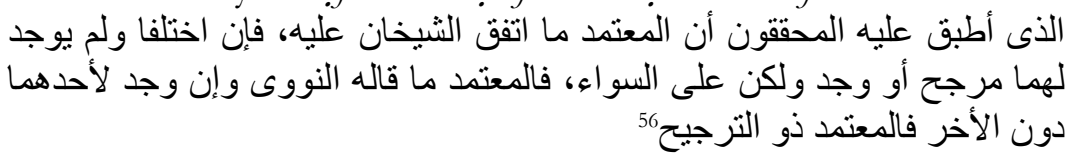

Para ulama bersepakat bahwa pendapat yang bisa dijadikan pegangan (dalam mazhab Shâfi î̀), ialah pendapat yang disepakati al-shaykkhânî (alNawawî dan al-Râfi î̀). Namun, apabila keduanya berbeda pendapat, dan tidak terdapat dalil pendukung (murajizi) yang mendukung keduanya, atau ada dalil pendukung tetapi sama kuatnya, maka pendapat alNawawîlah yang dijadikan pegangan. Tetapi, jika ditemukan dalil pendukung bagi salah satu pendapat mereka, maka pendapat itulah yang bisa dijadikan pegangan.

Pernyataan yang senada juga disampaikan oleh al-Ramlî:

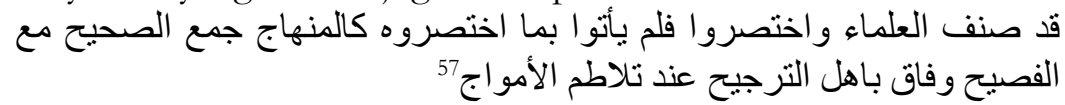

Telah banyak ulama yang mengarang maupun me-resume kitab, tetapi tidak ada kitab dalam bentuk mukbtasar yang menyamai kitab al-Minhâj (karya al-Nawawî). Kitab tersebut memadukan pendapat-pendapat yang sahîh yang tertata dengan baik. Kitab al-Minhâj sangat berguna bagi abl altarjî̀ (penyeleksi), ketika terjadi banyak pendapat yang berbeda.

\footnotetext{
${ }^{54}$ Kitab ini dicetak beberapa kali dan mempunyai dua hâshiyah, yaitu Hâshiyat al'Allâmah Ạ̣mad b. Qâsim al-Ubadî (w. 994 H.), dan Hấshiyat al-'Allâmah 'Abd alHamîd al-Sharwanî.

${ }^{55}$ Kitab ini juga dicetak beberapa kali serta mempunyai dua hâshiyah, yakni Hâashiyah al-'Allâmah Nûr al-Dîn 'Alì b. 'Alî al-Shibrâmalî̀î̀ (w. 1087 H) dan Hâshiyah al-'Allâmah Aḥmad 'Abd al-Razzâq yang dikenal dengan sebutan al-Maghribî al-Râshidî (w. 1096 H.).

${ }^{56}$ Muhammad, al-Madkhal ilâ Dirâsat al-Madhâbib, 49.

${ }^{57}$ Shihâb al-Dîn al-Ramlî, Nihâyat al-Mụ̣tâj, Vol. 1, 3.
} 
Pernyataan Ibn Hajar al-Haytamî dan al-Ramlî di atas, menunjukkan bahwa ia ingin meneguhkan pendapat al-Raficî dan alNawâwi sebagai pendapat yang kuat dan dapat dijadikan pegangan dalam mazhab Shâfîî. Oleh karena itu, al-Haytamî dan tiga tokoh lainnya dikenal sebagai tokoh pemantapan mazhab Shâfíî.

Hasil tarjîh Ibn Hajar al-Haytamî yang termuat di dalam kitab Tuhfat al-Mubtâj dan hasil tarjîh al-Ramlî yang termuat di dalam kitab Nihâyat al-Muḅtâj menjadi pegangan kedua bagi ulama Shâfiîyah setelah pendapat al-Râfíî dan al-Nawawi. ${ }^{58}$ Apabila al-Haytamî dan alRamlî tidak membahas satu persoalan atau membahasnya tapi terlalu singkat, maka yang banyak diambil oleh ulama Shâfiî̀yah adalah pendapat Shaykh al-Islâm Abû Zakarîyâ al-Anșarî (w. 926 H.), yang termuat dalam kitab al-Manhaj, ringkasan dari kitab Minhâj al-Tâlibin dan kitab al-Ghurar al-Bahîyah fî Sharḅ Manzumât al-Babjah al-Wardîyah. ${ }^{59}$ Setelah pendapat al-Ansârî, pendapat yang dipandang otoritatif dalam mazhab Shâfíî adalah pendapat al-Khatîb al-Sharbînî (w. 977 H.) yang termuat dalam kitab Mughnî al-Mubtâj ilâ Ma'rifat al-Ma'ânî Alfâz alMinhâj, sharh kitab Minhâj al-Tâlibîn. ${ }^{00}$ Setelah pendapat al-Khaṭ̂ib alSharbînî, maka pendapat otoritatif berikutnya adalah hasil ijtihâd Shihâb al-Dîn al-Qalyûbî yang termuat dalam kitab Hâshiyah Qalyûbî Umayrah dan hasil ijtihâd Shaykh Umayrah yang termuat dalam Sharl. al-Mahalli. ${ }^{61}$

Persoalan berikutnya, bagaimana apabila antara Ibn Hajar alHaytamî dengan Shams al-Dîn al-Ramlî terjadi pertentangan pendapat? Sebagaimana pertentangan antara Imam al-Râfi î dengan Imam al-Nawawî, antara Ibn Hajar al-Haytamî dan Shams al-Dîn alRamlî juga perbedaan pendapat, hanya saja perbedaan tersebut tidak sebanyak perbedaan antara Imam al-Nawawî dengan al-Râfî̀.

Dalam hal ini, terjadi perbedaan pendapat antara ulama Mesir dengan ulama Hịâz. Bagi ulama Mesir, pendapat al-Ramlî yang harus diawalkan, khususnya apa yang tertuang dalam kitabnya Nibâyat alMuḅtaj. Pendapat ini didasarkan pada fakta historis, bahwa kitab

\footnotetext{
58 Muhammad, al-Madkhal ilâ Dirâsat al-Madhâhib, 49.

${ }^{59}$ Ibid.

${ }^{60}$ Kitab ini juga dicetak dan sangat terkenal di kalangan mazhab Shâfî̀, serta dijadikan referensi utama di lingkungan Fakultas Syariah Universitas al-Azhar Kairo, Mesir.

${ }^{61}$ Muḥammad, al-Madkhal ilâ Dirâsat al-Madhâhib, 49. 
tersebut telah disodorkan untuk dibaca dan mendapatkan masukan dari sekira empat ratus ulama, sehingga keabsahan kitab tersebut mutawatir dan karenanya harus didahulukan dari yang lain. ${ }^{62}$ Sedangkan ulama Hijâz, Hạ̣r Mawt, Shâm, dan Yaman berpendapat bahwa yang harus diambil adalah pendapat Ibn Hajar al-Haytamî khususnya yang tercantum dalam kitab Tubfat al-Mubtâj. Hal ini dikarenakan kitab tersebut mencakup juga nuşus dari Imam al-Haramayn al-Juwaynî. ${ }^{63}$

Setelah masa al-Nawawî, yaitu mulai masa Ibn Hajar al-Haytamî dan Shihâb al-Dîn al-Ramlî, terjadi penyederhanaan prosedur ijtihâd intiqầi. Jika al-Nawawî dan ulama-ulama sebelumnya melakukan penyeleksian pendapat berdasarkan tingkat validitas dalil, maka pada era mujtabid fî̀ al-fatwâ, seperti Ibn Hajar al-Haytamî dan al-Ramlî, pemilihan pendapat yang terkuat, lebih didasarkan pada otoritas dan ketokohan pemilik pendapat. Maka diputuskanlah bahwa pendapat alNawawî dan pendapat al-Râfîî merupakan pendapat yang paling otoritatif dalam kasus perbedaan pendapat hukum.

\section{Pengaruh Tarjîh al-Râfíî dan al-Nawawî di Indonesia}

Di Indonesia, Nahdlatul Ulama (NU) dalam membuat keputusan hukum menjunjung tinggi hasil tarjîh Imam al-Râfîî dan Imam alNawawî. Hal tersebut dapat dilihat dari prosedur seleksi pendapat di forum bahth al-masâ'il NU dikenal dengan istilah taqrîr jama'î. Dasardasar umum penetapan fatwa dalam bahth al-masâ'il adalah:

a. Dalam kasus ketika jawaban bisa dicukupi oleh 'ibârât kitâb dan di sana hanya terdapat satu qawl atau wajh, maka dipakailah qawl/wajh itu sebagaimana diterangkan dalam 'ibârât kitâb tersebut.

b. Dalam kasus ketika jawaban bisa dicukupi oleh 'ibârât kitâb dan di sana ternyata terdapat lebih dari satu qawl atau wajh, maka dilakukan taqrîr jama'ı̂ untuk memilih satu qawl atau wajh. ${ }^{64}$

Dari diktum di atas, dapat dipahami bahwa pertama, taqrî jama $\hat{\imath}$ merupakan prosedur pelaksanaan dari bermazhab secara qawli, yaitu upaya penjawaban suatu masalah dengan cara merujuk teks-teks kitab kuning. Kedua, taqrîr jama'i adalah upaya secara kolektif untuk

62 Ibid., 50.

${ }^{63}$ Ibid.

${ }^{64}$ Keputusan Munas Alim Ulama Nahdlatul Ulama di Bandar Lampung tahun 1992,

"Sistem Pengambilan Keputusan Hukum dalam Baḅth al-Masẩil di Lingkungan Nahdlatul Ulama", dalam LTN-PBNU, Aḥkâm al-Fuqahâ': Solusi Problematika Aktual Hukum Islam, Keputusan Muktamar, Munas, dan Konbes Nabdlatul Ulama 1926-2010 (Surabaya: Khalista, 2011), 470. 
menetapkan pilihan qawl atau wajh mana yang paling kuat jika dalam 'ibârat kitab kuning ditemukan beragam pendapat.

Petunjuk operasional tentang pemilihan qawl atau wajh atau prosedur taqrî jama ‘̂, pertama kali diputuskan pada Muktamar NU I di Surabaya tahun 1926. Muktamar memutuskan, bahwa jika terjadi perbedaan pendapat di antara fuqaha, maka hirarki pemilihannya, sebagai berikut:

a. Memilih pendapat yang disepakati oleh al-Shaykhân (al-Nawawî dan al-Râfíî).

b. Memilih pendapat yang dipilih Imam al-Nawawî saja.

c. Pendapat yang dipilih oleh Imam al-Râfi'î saja.

d. Pendapat yang disokong oleh mayoritas ulama.

e. Pendapat ulama yang terpandai.

f. Pendapat ulama yang paling wirầ $\hat{\imath}^{65}$

Keputusan tersebut didasarkan pada 'ibârat (teks) kitab I'ânat alṬâlibîn:

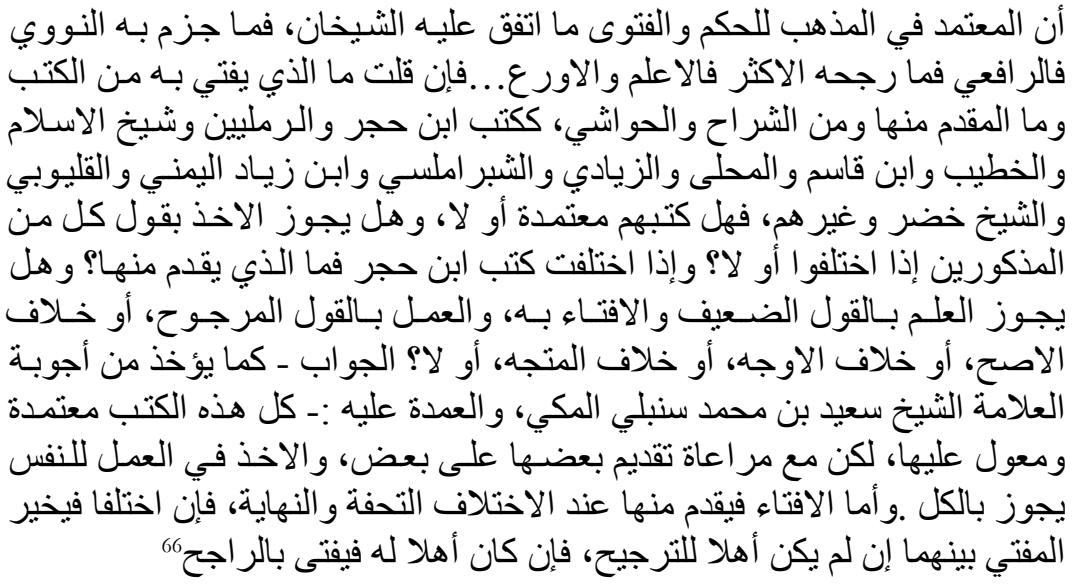

Sesungguhnya, pendapat yang bisa dijadikan pegangan untuk menetapkan hukum dan berfatwa di dalam mazhab (Shafi î) adalah (secara hirarkis) sebagai berikut: pendapat yang disepakati al-Shaykhân (Imam al-Nawawî dan Imam al-Râfîî), lalu pendapat al-Nawawî, pendapat al-Râfi î̀, pendapat yang didukung mayoritas ulama, pendapat orang yang paling álim, pendapat orang yang paling sâlị̣ (wira î)... apabila anda bertanya, "kitab-kitab apa yang bisa dijadikan pedoman

${ }^{65}$ LTN PBNU, Aḅkâm al-Fuqahâ؛: Solusi Problematika Aktual Hukum Islam (Surabaya: Khalista, 2011), 3.

${ }^{66}$ Muhammad Shatâ al-Dimyâtî, I'ânat al-Tâlibîn, Vol. 4 (Surabaya: Nur Aziz, t.th.), 19. 
dalam berfatwa di antara kitab-kitab sharh (komentar), ḅâshiyah (notasi) seperti karya-karya Ibn Hajar, dua imam Ramlî (Shihâb al-Dîn al-Ramlî dan Shams al-Dîn al-Ramlî), Shaykh al-Islâm, al-Khatîib al-Sharbînî, Ibn al-Qâsim, al-Mahallî, al-Zayyyâdî, al-Shibrâmalisî, Ibn Ziyâd al-Yamanî, al-Qalyûbî dan yang lain? Apakah boleh merujuk kepada salah satu dari kitab-kitab tersebut, di saat mereka berbeda pendapat? Jawabannya, sebagaimana dikemukakan oleh Saî̀ b. Muhammad Sunbulî al-Makkî, semua kitab tersebut mu'tamad (bisa dijadikan pegangan), tentu dengan keharusan memperhatikan urutan mana yang didahulukan. Semuanya bisa diambil untuk kepentingan pribadi. Akan tetapi, jika untuk berfatwa, sedangkan pendapat-pendapat berbeda maka harus diprioritaskan al-Tubfah (karya Ibn Hajar) dan al-Nibâyah (karya Shams al-Dîn al-Ramlî). Jika keduanya berbeda pendapat, dan orang tidak memiliki kemampuan menyeleksi (tarizh) mana yang lebih kuat, maka dia boleh memilih salah satu dari keduanya. Jika dia mampu menyeleksi, maka pendapat yang kuatlah yang dijadikan pedoman dalam berfatwa.

Dari rumusan prosedur taqrîr jama $\hat{\imath}$ di atas, ada beberapa hal yang perlu dijelaskan lebih lanjut. Disebutkan bahwa pendapat al-Nawawî lebih diunggulkan daripada pendapat al-Râfíî ketika keduanya berbeda pandangan. Beberapa ahli mengemukakan alasannya. Di antara mereka, Husein Muhammad menyebutkan empat hal kelebihan al-Nawawî dibanding al-Râfîî, yaitu: 1) al-Nawawî dikenal sebagai muharrir (penyeleksi) dalam mazhab Shâfî̀. 2) al-Nawawî dikenal sebagai faqû̉ dan muḥaddith 'áqil, sementara al-Râfiî̀ hanyalah faqîh. AlNawawî memiliki banyak karya kitab hadîth seperti Sharh Muslim, alAdhkâr, al-Khulâsah fì al-Hadìth, sedangkan al-Râfî̀ tidak memiliki karya ḥadîth. 3) al-Nawawî memiliki kecenderungan asketis yang lebih tinggi dibanding al-Râfîî.

Konon, ada yang mengatakan, apabila al-Râfî̀̂ menulis, maka penanya bersinar, sementara jika al-Nawawî menulis, jari-jarinya yang bercahaya. ${ }^{67}$ Sedangkan Idrus Romli melihat kelebihan al-Nawawî pada proses penyeleksiannya terhadap pendapat-pendapat aș̣âb al-

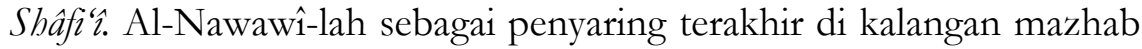
Shâfiî̀. Lebih lanjut ia mengatakan "setelah pendapat așhâab al-Shâfi î itu dikoreksi oleh al-Râfîî, dikoreksi lagi oleh al-Nawawî. Jadi di tangan al-Nawawî, pendapat aṣhâb semakin murni."

${ }^{67}$ Husein Muhammad, "Tradisi Istinbat Hukum NU: Sebuah Kritik", dalam M. Imdadun Rahmat (ed.), Kritik Nalar Fiqh NU: Transformasi Paradigma Babtsul Masa'il (Jakarta: Lakpesdam, 2002), 28-29.

${ }^{68}$ Idrus Romli, Wawancara, Surabaya, 25 Desember 2011. 
Jawaban lain menyatakan bahwa al-Nawawî diunggulkan karena keberhasilannya merumuskan kriteria tarith seperti al-az̧har, al-mashbûr, al-naș, al-madhhab, dan sebagainya sebagaimana yang disebutkan dalam al-Majmû dan al-Minhâj. Bahkan melalui kedua kitab tersebut, alNawawî banyak mengoreksi pendapat-pendapat al-Râfîî. Misalnya dalam masalah kulit yang disamak, apakah bagian dalam kulit tersebut menjadi suci juga dengan cara disamak, seperti kulit bagian luarnya? Ataukah yang menjadi suci hanya bagian luarnya saja? Dalam hal ini, al-Râfîî menyebutkan bahwa menurut qawl jadî̀, kulit tersebut suci bagian luar dan dalamnya, sehingga bisa dijadikan sebagai bahan baku pakaian, sajadah, bisa diperjual belikan, bisa dimanfaatkan baik kondisi kering dan basah. Sedangkan menurut qawl qadim, bagian dalam kulit tidak bisa menjadi suci. Artinya, kulit tersebut hanya bisa dijadikan alas untuk salat dan tidak boleh dijadikan bahan pakaian yang dipakai ketika salat. Konsekuensinya, kulit itu pun tidak boleh dijual dan tidak boleh dimanfaatkan pada kondisi basah. Imam alNawawî kemudian mengoreksi pendapat al-Râfíî tersebut dengan menyandarkan pada qawl qadîm. Menurut al-Nawawî, pendapat yang dikemukakan al-Rafi î yang kedua tersebut bukanlah qawl qadìm, melainkan pendapat Imam Mâlik. Menurut al-Nawawî, tidak ada perbedaan antara qawl qadîm dengan qawl jadìd dalam masalah kulit yang disamak, bahwa bagian luar maupun dalam dihukumi suci. ${ }^{69}$

\section{Penutup}

Berdasarkan tilikan dengan teori tarîth sebagaimana dikonsepkan di dalam literatur usûl al-fiqh, apa yang dilakukan oleh kedua imam mazhab Shâfîi di atas adalah tarį̀̆ yang menggabungkan pengujian kekuatan dalil dan penghormatan kepada otoritas mazhab, dalam arti mendahulukan mengikuti ulama yang lebih otoritatif tanpa banyak menguji lagi argumentasi mereka. Penghomatan kepada otoritas seperti ini lebih konkret lagi digunakan oleh generasi sesudah al-Râfi î dan al-Nawawî. Langkah gabungan seperti ini merupakan hal yang tidak dikonsepkan di dalam usûul al-figh, sehingga gagasan baru ini perlu dikaji lebih lanjut mengenai maknanya di dalam afiliasi kemazhaban dengan pertanyaan pokok apakah mazhab itu merupakan sejenis kesatuan sikap berbasis ilmiah ataukah berkat direkatkan oleh faktorfaktor non-ilmiah, termasuk misalnya primordialisme.

${ }^{69}$ al-Nawawî, al-Majmû́, Vol. 1, 227-228. 
Terlepas dari itu semua, apa yang kemudian diwarisi oleh generasi Muslim sekarang adalah sebuah aliran pemikiran hukum yang memiliki kekayaan intelektual yang demikian besar. Aliran ini juga menyediakan petunjuk umum untuk mengelola penggunaan kekayaan itu untuk keperluan implementasinya dalam kehidupan sehari-hari sehubungan dengan keanekaragaman pendapat yang ada di dalamnya. Memang petunjuk itu tidaklah demikian rinci, sehingga masih tersedia ruangan bagi pemikir sekarang untuk mengerahkan daya intelektualnya dalam implementasi pendapat-pendapat itu dengan mempertimbangkan kemaslahatan kontemporer, setelah semua pendapat itu dibersihkan dari unsur-unsur kelemahan dalil dan kecenderungan menyendiri atau eksklusif yang tidak terkontrol oleh mayoritas.

\section{Daftar Rujukan}

Âmidî (al), Sayf al-Dîn. Al-Iḥkâm fî Usûl al-Aḥkâm. Beirut: Dâr alKutub al-'Ilmîyah, 1983.

Abû Zahrah, Muhammad. Usûul al-Fiqh. t.t.: Dâr al-Fikr, t.th.

Dimyâṭ̂i (al), Muhammad Shața. I'ânat al-Tâlibîn. Surabaya: Nur Aziz, t.th.

Djamil, Fathurrahman. Metode Ijtihâd Majelis Tarjih Muhammadiyah. Jakarta: Logos Pablishing House, 1987.

Haroen, Nasrun. Ushul Fiqh I. Jakarta: Logos Wacana, 2001.

Haytamî (al), Ibn Hajar. Tuhfat al-Mụ̣tâj bi Sharḅ al-Minhâjj. Beirut: Dâr al-Fikr, t.th.

Jum'ah, Muḥammad 'Alî. Al-Madkhal ilâ Dirâsat al-Madhâhib alFiqhîyah. Kairo: Dâr al-Salâm, t.th.

Jurjânî (al), 'Alî b. Muhammad b. 'Alî. al-Ta'rîfât. Singapura: alHaramayn, t.th.

Khallikân, Ibn. Wâfayât al-Áyân. Beirut: Dâr al-Fikr, 1985.

LTN-PBNU. Aḅkâm al-Fuqabâ: Solusi Problematika Aktual Hukum Islam, Keputusan Muktamar, Munas dan Konbes Nabdlatul Ulama 19262010. Surabaya: Khalista, 2011.

Maḥallî (al), Jalâl al-Dîn. Hâshiyatayn al-Qalyûbî wa Umayrah. Semarang: Toha Putra, t.th.

Muhammad, Husein. "Tradisi Istinbat Hukum NU: Sebuah Kritik", dalam M. Imdadun Rahmat. Kritik Nalar Fiqh NU: Transformasi Paradigma Bahtsul Masâill. Jakarta: Lakpesdam, 2002. 
Nawawî (al), Yahyâ b. Sharaf. Al-Majmû́: Sharḥ al-Muhadhdhab. Beirut: Dâr al-Kutub al-'Ilmîyah, 1980.

. Minhâj al-Tâlibîn wa Umdat al-Muftîn. Jeddah: Dâr al-Minhâj, 2005.

-----. Rawdat al-Ṭâlibîn. Beirut: Dâr 'Âlim al-Kutub, t.th.

Qarḍ̂âî (al), Yûsuf. Al-Ijtihâd fî al-Sharîah al-Islâmîyah. Kuwait: Dâr alQalam, 1985.

-----. Ijtihad Kontemporer: Kode Etik dan Berbagai Penyimpangan, terj. Abu Barzani. Surabaya: Risalah Gusti, 1995.

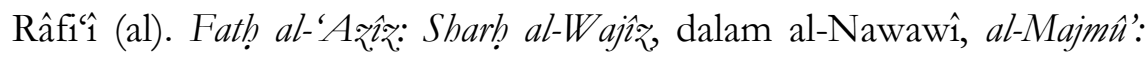
Sharḅ al-Muhadhdhab. Beirut: Dâr al-Kutub al-'Ilmîyah, 1980.

Ramlî (al), Shams al-Dîn. Nibâyat al-Mubtâj ilâ Sharḥ al-Minhâj. Beirut: Dâr al-Kutub al-'Ilmîyah, t.th.

Salam, Ahmad Nahrowi Abdus. Ensiklopedia Imam Syafi $i$, terj. Usman Sya'roni. Jakarta: Hikmah, 2008.

Sharbînî (al), Muhammad al-Khatîib. Mughnî al-Muḅtâj ilâ Ma'rifat Alfầ. al-Minhâj. Beirut: Dâr al-Fikr, t.th.

Shawkânî (al), Muhammad b. 'Alî b. Muhammad. Irshâd al-Fuḅ̂ll. Beirut: Dâr al-Fikr, t.th.

Subkî (al), Tâj al-Dîn Abû Nașr 'Abd al-Wahhâb. Țabaqât al-Shâfi îyah al-Kubrâ, Vol. 5. Mesir: Fayșal 'Îsâ al-Bâbî al-Halabî, 1964.

Syafe'i, Rachmat. Ilmu Ushul Fiqih. Bandung: Pustaka Setia, 1999.

Yûnanî (al), Abû al-Fath Mûsâ b. Muhammad. Dhayl Mir'ât al-Zamân. India: al-Maṭba'ah al-'Uthmânîyah, $1374 \mathrm{H}$.

Zuhaylî (al), Wahbah. Ușûl al-Fiqh al-Islâmî. Beirut: Dâr al-Fikr, 1998. 